\title{
BODY IMAGE SISWA DITINJAU DARI GENDER
}

\author{
Fauzana Alidia \\ Praktisi Bimbingan dan Konseling Berdomisili di Jakarta \\ email: fauzanaalidia@gmail.com
}

\begin{abstract}
Body image is a description of perceptions, feelings and attitudes about the body as a whole person or a particular the part of body. The differences of body image are influenced by several aspects; one of them is gender. The aims of this research are :1) to describe the body image of male students, 2) to describe the body image of female students, and 3) to find out the differences of body image between male and female students. This is a descriptive research by using quantitative approach. The population of this research was the students of grade XI SMA Negeri Tanjung Mutiara in the academic year of 2013/2014. The amount of the sample was 56 male students and 110 female students that been chosen by using simple random technique. The instrument that had been used was Likert scale model. The first and second research purposes were analyzed using percentage technique, and the third research purpose was analyzed using t-test. The results of research are: 1) Body image of male students are in the high category, 2) Body image of female students are in the high category, 3) There is a difference between male body image and female body image.
\end{abstract}

Keyword: Body Image, Gender

\begin{abstract}
Abstrak: Body image merupakan persepsi, perasaan dan sikap tentang seluruh tubuh atau bagian tubuh tertentu. Perbedaan body image dipengaruhi oleh beberapa aspek, salah satunya yakni gender. Tujuan penelitian ini antara lain: 1) mendeskripsikan body image siswa laki-laki, 2) mendeskripsikan body image siswa perempuan, dan 3) untuk mengetahui perbedaan body image antara siswa laki-laki dan siswa perempuan. Penelitian ini merupakan penelitian kuantitatif dengan menggunakan jenis penelitian komparatif. Populasi dalam penelitian ini adalah siswa kelas XI SMA Negeri Tanjung Mutiara pada periode 2013/2014. Jumlah sampel penelitian sebanyak 56 siswa laki-laki dan 110 siswa perempuan yang dipilih dengan menggunakan teknik acak sederhana. Instrumen yang digunakan adalah skala Likert. Tujuan penelitian pertama dan kedua dianalisis dengan menggunakan teknik persentase, dan tujuan penelitian ketiga dianalisis dengan menggunakan t-test. Hasil penelitian antara lain: 1) body image siswa laki-laki berada dalam kategori tinggi, 2) body image siswa perempuan berada dalam kategori tinggi, 3) Ada perbedaan antara body image laki-laki dan citra tubuh perempuan.
\end{abstract}

Kata kunci: Body Image, Gender 


\section{PENDAHULUAN}

Siswa Sekolah Menengah Atas (SMA) berada pada tahapan perkembangan remaja. Remaja pada tingkat sekolah menengah pertama berada pada tingkat perkembangan yang disebut "masa remaja atau pubertas". Pudjijogyanti (1986: 30) mengungkapkan bahwa masa remaja merupakan masa peralihan atau masa transisi, dimana remaja belum sungguh-sungguh dikatakan dewasa dan sudah tidak bisa lagi dikatakan kanak-kanak. Djahwat dalam Lilis Suryani (2012:1) menjelaskan bahwa remaja yang sedang mengalami proses transisi atau pubertas memiliki ciri-ciri dalam pertumbuhan fisik, psikis, dan sosialnya. Pada masa remaja merupakan masa transisi pertama,atau masa peralihan dari tingkat sekolah dasar ke tingkat menengah pertama. Transisi di sekolah menengah pertama membuat siswa perempuan mengalami perubahan fisik pada masa pubertas ketika mereka berada pada konteks yang luas dan impersonal dari sekolah menengah. Namun sekolah menengah tidak mengurangi frekuensi remaja menjadi siswa paling muda. Para siswa laki-laki akan lebih banyak mengalami lebih banyak tekanan dibandingkan sebelumnya karena perubahan pubertas mereka berlangsung bersamaan dengan perubahan fisik. Jhon W. Santrock (2007:106). Senada dengan pendapat Pudjijogyanti (1986: 30) bahwa tekanan yang muncul pada diri remaja salah satunya dipicu karena terjadinya perubahan pada fisik remaja, yaitu perkembangan tanda kelamin sekunder, yang menimbulkan rasa aneh dan tidak nyaman serta berbeda dengan remaja yang lain. Akibat yang timbul dari hal tersebut remaja akan menjadi salah tingkah dan bingung yang menyebabkan timbulnya rasa tidak puas terhadap dirinya. Perasaan tidak puas terhadap dirinya menunjukan bahwa remaja menolak tubuhnya. Berdasarkan hasil penelitian yang dilakukan oleh Pini Pitria (2010) yang berjudul Permasalahan Yang Dihadapi Siswa Pada Masa Pubertas. Menunjukan bahwa permasalahan yang dihadapi siswa pada masa pubertas diantaranya siswa kesulitan mengatur berat badan, siswa merasa malu dengan wajah yang berjerawat, dan siswa merasa kesakitan pada tubuh saat menstruasi, dari hasil penelitian tersebut dapat dipahami bahwa individu yang memasuki masa remaja akan dihadapkan pada berbagai masalah dalam mengahadapi perubahan fisiknya sehingga berpengaruh terhadap pembentukkan konsep diri remaja pada masa pubertas. Kondisi dan situasi yang seperti ini tentu sangat mempengaruhi pembentukan body image remaja yang akan menjadi dasar konsep diri remaja.

Menurut Holigman dan Castle body image adalah gambaran atau mental seseorang terhadap bentuk dan ukuran tubuhnya, dan atas bagaimana kira-kira penilaian orang lain terhadap dirinya. Maynard (2008) mengungkapkan body image adalah gambaran mental seseorang terhadap tubuhnya seperti pikiran mereka, perasaan, pendapat, sensasi, kesadaran, 
dan perilaku. Body image dikembangkan melalui interaksi dengan orang lain dan lingkungan sosial.

Seorang remaja yang memandang serta menilai tubuhnya sendiri sesuai dengan apa yang dia inginkan maupun dengan ideal yang ada, maka jelas akan memberikan keuntungan positif bagi diri remaja itu sendiri. Body image yang positif atau yang sehat, seorang remaja akan mempunyai penilaian atau pandangan yang baik terhadap ukuran dan bentuk tubuh mereka dan mereka merasa nyaman dengan keadaan tubuhnya itu yang akan diwujudkan dalam sikap percaya diri dan konsep diri yang sehat. Contohnya saja seorang remaja yang berperilaku positif terhadap dirinya sendiri adalah seorang remaja yang mampu menerima bagian dari tubuh mereka, sebagaimana yang telah dianugerahi oleh tuhan terhadap dirinya. Seperti, mereka menghargai tubuh mereka sendiri, merasa bangga dan menerima tubuh mereka dan menolak yang tidak masuk akal untuk merasa nyaman dan percaya diri dengan tubuhnya.

Dengan Body image yang negatif, seorang remaja itu akan memiliki pandangan yang negatif juga terhadap bentuk serta ukuran tubuhnya, atau orang-orang disekitarnya yang sebaya dengan mereka itu, dan merasa minder serta khawatir tentang tubuh mereka sehingga mereka menjadi individu yang tidak puas dengan dirinya sendiri. Menjadi sulit menerima diri apa adanya, peka terhadap kritikan, tidak merespon pujian dan pesimis sendiri, dengan keadaan dirinya sendiri.

Para remaja sekarang menjadi tidak senang lagi dengan tubuhnya sendiri, dan hal itu sangat mempengaruhi bagaimana remaja itu berpikir dan merasakan tentang dirinya. Kepercayaan diri yang rendah, perilaku pola makan yang tidak sehat, kekhawatiran, serta prustasi dengan diri sendiri secara langsung mengakibatkan emotional distress yang mana sangat mempengaruhi Body image kita melemah atau jelek.

Tentunya remaja ataupun dewasa sangat menginginkan kondisi tubuh yang baik, namun tubuh yang sehat tidak selalu dikaitkan dengan penampilan. Kenyataannya, tubuh kita yang sehat muncul dari semua bentuk serta ukuran. Pada hal yang sama life Style yang sehat merupakan cikal bakal untuk meningkatkan Body image.

Pandangan serta penilaian yang negatif tentang tubuh maka akan negatif pula yang dirasakan oleh remaja tentang dirinya itu.ketika sebagian besar orang berfikir tentang aspek dari fisik, penampilan, keadaan menarik dan cantik. Akan tetapi Body image itu sendiri lebih dari apa yang orang pikirkan. Body image yang sehat terjadi ketika seseorang merasa positif tentang tubuhnya, yakin dan peduli dengan diri.

Faktanya banyak pada remaja kita sekarang mempunyai masalah terhadap dirinya sendiri, mereka berusaha menutupi masalah itu, tidak merasa memiliki masalah ketika 
dihadapkan kepada penampilan mereka. Pandangan serta penilaian seseorang terhadap bagianbagian tubuhnya maupun penampilan fisik secara keseluruhan yang dipikirkan dan dirasakan belum benar-benar memperlihatkan keadaan yang sebenarnya, namun lebih merupakan hasil penilaian diri yang subyektif. Remaja melihat diri mereka sendiri memiliki kelebihan berat badan, bahkan pada saat orang lain menganggap bahwa mereka langsing. Kesadaran akan adanya reaksi sosial terhadap berbagai bentuk tubuh menyebabkan remaja merasa kecewa akan pertumbuhan tubuhnya yang tidak sesuai dengan apa yang dia inginkan.

Chase (2001) menjelaskan bahwa jenis kelamin adalah faktor paling penting dalam perkembangan body image seseorang. Dacey \& Kenny (2001) juga sependapat bahwa jenis jenis kelamin mempengaruhi body image. Siswa perempuan lebih cenderung mengutamakan penampilan fisik mereka sendiri, mereka berpikir tentang aspek dari fisik, penampilan, keadaan menarik dan cantik.

Berdasarkan penelitian yang dilakukan Kakekshita dan Almeida (2008) ditemukan hasil bahwa remaja perempuan cenderung terlalu melebih-lebihkan ukuran tubuhnya dibandingkan remaja laki-laki. Hasil penelitian Setyorini (2010) mengemukakan terdapat 51,6\% remaja perempuan puas terhadap bentuk remaja perempuan puas terhadap bentuk dan ukuran tubuhnya, sedangkan 48,4\% merasa tidak puas. Terdapat 51,6 \% remaja putri memiliki tingkat pengetahuan gizi baik, 41,9\% cukup, dan 6,5\% kurang. Terdapat hubungan yang bermakna antara body image dengan perilaku makan remaja putri, tidak terdapat hubungan antara pengetahuan gizi dengan pola makan remaja putri. Hasil penelitian Kusumajaya,dkk (2007) diperoleh hasil $41,1 \%$ responden merasa memiliki berat badan yang lebih dibandingkan dengan keadaan yang sebenarnya, yaitu merasa diri gemuk tapi sebenarnya kurus, merasa normal tapi sebenarnya kurus dan merasa gemuk tapi sebenarnya normal. Kejadian ini cenderung terjadi pada remaja putri, yaitu sekitar 45,2\% sedangkan pada remaja putra sekitar $35 \%$. Keinginan untuk menurunkan berat badan lebih banyak terjadi pada remaja putri 37,6\% dibandingkan remaja putra 37\%. Ada perbedaan status ketidakpuasaan body image antara lakilaki dan perempuan, dimana laki-laki yang obesitas mempunyai peluang yang jauh lebih kecil untuk tidak puas terhadap body image dibandingkan dengan perempuan.

Berdasarkan hasil obervasi yang dilakukan peneliti pada tanggal 16 oktober 2013 di SMA N 1 Tanjung Mutiara, pada umumnya remaja sudah memasuki masa pubertas, yaitu tumbuhnya rambut-rambut halus di sekitar daerah istimewa seperti, kumis pada remaja pria, di bawah ketiak, dan di daerah sekitar alat kelamin. Payudara yang mulai membesar, panggul yang mulai membesar pada remaja wanita. Ada sebagian siswa yang merasa minder dan tidak percaya diri dengan adanya perubahan yang pada diri mereka tersebut. Sehingga ini 
berpengaruh terhadap body image siswa, yakni bagaimana mereka menilai dan memahami diri mereka.

Berdasarkan hasil wawancara peneliti pada tanggal 18 oktober 2013, adanya beberapa siswa yang minder dalam bergaul, karena memiliki bentuk fisik yang kurang sempurna. Adanya siswa yang merasa terganggu ketika mengalami menstruasi pertama di sekolah, sehingga mengakibatkan proses belajarnya terganggu. Dari hasil wawancara dengan konselor di sekolah, adanya siswa yang terisolir karena perubahan fisik yang dimilikinya. Remaja malu dengan jerawat di wajahnya sehingga membuatnya tidak percaya diri ketika disuruh tampil di depan kelas oleh gurunya.

Dari hasil pengamatan peneliti pada tanggal 23 oktober 2013 dengan 10 orang remaja perempuan dan 5 orang remaja laki-laki di SMA N 1 Tanjung Mutiara, yaitu remaja perempuan merasa tidak puas dengan penampilan fisiknya, karena remaja merasa panggulnya yang berubah menjadi lebar, keringat yang banyak, payudara yang mulai membesar membuat remaja merasa malu dan pakaian yang sering dipakai oleh remaja menjadi sempit. Remaja lakilaki merasakan kulitnya berubah menjadi kasar, timbulnya jerawat membuat remaja merasa malu, canggung dan tidak percaya diri terutama kepada remaja perempuan. Keringat yang banyak membuat remaja sering menjauh dari temannya karena remaja merasa keringatnya menyebabkan bau badan. Rambut di kepala yang mudah berminyak membuat remaja gatalgatal dan tidak nyaman sehingga konsentrasi belajar menjadi tergangggu.

Berdasarkan latar belakang yang telah diuraikan, maka rumusan masalah yang akan diteliti adalah: Bagaimana Body Image Siswa ditinjau dari Gender serta Implikasinya terhadap Layanan Bimbingan dan Konseling?. Tujuan penelitian ini untuk: 1) mendeskripsikan body image siswa laki-laki yang meliputi aspek perseptual, afektif, kognitif, dan perilaku; 2) untuk mendeskripsikan body image siswa perempuan yang meliputi aspek perseptual, afektif, kognitif, dan perilaku; dan 3) untuk mengidentifikasi perbedaan body image siswa laki-laki dan perempuan

\section{METODOLOGI}

Berdasarkan permasalahan, pembatasan masalah dan tujuan penelitian maka jenis penelitian yang akan digunakan adalah penelitian deskriptif komparatif. Dalam penelitian ini yang akan menjadi populasi adalah siswa laki-laki dan perempuan kelas XI SMA N 1 Tanjung Mutiara yang terdaftar pada tahun ajaran 2013/2014 sebanyak 285 siswa. Sampel diambil dengan menggunakan teknik simple random sampling sebanyak 166 siswa dengan rincian 56 siswa laki-laki dan 110 siswa perempuan. Instrumen yang digunakan untuk mengumpul data 
dalam penelitian ini adalah angket. Teknik analisa data yang digunakan adalah t-test dengan asumsi bahwa data yang diperoleh telah lulus uji normalitas dan homogenitas.

\section{HASIL PENELITIAN DAN PEMBAHASAN}

\section{Hasil Penelitian}

Berdasarkan verifikasi terhadap data penelitian, seluruh data yang diperoleh dari hasil pengadministrasian terhadap siswa layak diolah yaitu sebanyak 166 data. Data penelitian ini meliputi body image siswa laki-laki dan siswa perempuan. Deskripsi mengenai body image siswa laki-laki dapat dilihat pada tabel berikut:

Tabel 1. Distribusi Frekuensi dan Kategori Skor Body Image Siswa Laki-laki (n=56)

\begin{tabular}{clcc}
\hline Interval Skor & \multicolumn{1}{c}{ Kategori } & Frekuensi (F) & Persentase $(\%)$ \\
\hline$\geq 173$ & Sangat Tinggi (ST) & 17 & 30.357 \\
\hline $159-172$ & Tinggi (T) & 16 & 28.571 \\
\hline $144-158$ & Sedang (S) & 15 & 26.786 \\
\hline $130-143$ & Rendah (R) & 5 & 8.929 \\
\hline$\leq 129$ & Sangat Rendah (SR) & 3 & 5.357 \\
\hline & Total & 56 & 100 \\
\hline
\end{tabular}

Dari tabel IV.1 di atas terlihat bahwa dari jumlah keseluruhan sampel yang berjumlah 56 siswa, sebagian besar Body Image siswa berada pada kategori sangat tinggi (ST) dengan jumlah frekuensi 17 siswa atau dapat dipersentasekan dengan nilai 30.357\%. Selanjutnya disusul pada kategori tinggi $(\mathrm{T})$ dengan jumlah frekuensi 16 siswa yang dapat dipersentasekan dengan nilai $28.571 \%$. Kategori sedang (S) dengan frekuensi sebanyak 15 siswa yang dapat dipersentasekan sebesar 26.786. Kategori rendah (R) yakni 5 siswa yang dapat dipersentasekan sebesar 8.929\%. Kemudian sangat rendah (SR) dengan frekuensi 3 siswa atau dapat dipersentasekan dengan nilai $5.357 \%$.

Pada variabel, pada semua indikator siswa berada pada kategori tinggi ( $\mathrm{T}$ ) dengan keseluruhan skor tertinggi yang dicapai sebesar 187 dari skor ideal yaitu 235. Skor terendah keseluruhan adalah 116, skor total mencapai 9055, rata-rata skor 161.696 dengan tingkat capaian keseluruhan responden sebesar $68.807 \%$ sehingga dapat diinterpretasikan dalam kategori tinggi (T) dengan standar deviasi berada pada nilai 16.907.

Selanjutnya untuk siswa perempuan, dari jumlah keseluruhan sampel yang berjumlah 110 siswa, sebagian besar body image mereka berada pada kategori tinggi (T) dengan jumlah frekuensi 55 siswa yang dapat dipersentasekan dengan nilai 50\%. Kategori sedang dengan 
jumlah frekuensi 34 siswa atau dapat dipersentasekan dengan nilai 30.909\%, Kemudian disusul pada kategori sangat tinggi (ST) dan rendah (R) yang frekuensinya berjumlah 14 dan 6 siswa atau dapat dipersentasekan dengan nilai $12.727 \%$ dan $5.455 \%$ dari seluruh responden. Pada kategori sangat rendah frekuensi hanya berjumlah 1 siswa atau sebesar 0.909\%. Deskripsi mengenai body image siswa perempuan siswa dapat dilihat pada tabel berikut:

Tabel 2. Distribusi Frekuensi dan Kategori Skor Body Image Siswa Perempuan ( $\mathrm{n}=110)$

\begin{tabular}{clcc}
\hline \multicolumn{1}{c}{ Kategori } & Frekuensi $(\mathrm{F})$ & Persentase $(\%)$ \\
\hline Interval Skor & \multicolumn{1}{c}{ Sangat Tinggi (ST) } & 14 & 12.727 \\
\hline 174 & Tinggi (T) & 55 & 50 \\
\hline $129-173$ & Sedang (S) & 34 & 30.909 \\
\hline $107-128$ & Rendah (R) & 6 & 5.455 \\
\hline$\leq 106$ & Sangat Rendah (SR) & 1 & 0.909 \\
\hline & Total & 110 & 100 \\
\hline
\end{tabular}

Selanjutnya pada variabel body image siswa perempuan, pada semua indikator berada pada kategori tinggi (T) dengan keseluruhan skor tertinggi yang dicapai sebesar 196 dari skor ideal yaitu 235. Skor terendah yakni 85, skor total mencapai 17004, rata-rata skor 154.582 dengan tingkat capaian keseluruhan responden siswa sebesar $65.779 \%$ sehingga dapat diinterpretasikan dalam kategori tinggi (T) dengan standar deviasi berada pada nilai 18.013.

Pengujian hipotesis dilakukan dengan uji $t$ atau $t$ tes. Persyaratan yang harus dipenuhi untuk uji $t$ atau $t$ tes, yaitu normalitas dan homogenitas. Pengujian normalitas data menggunakan tekhnik analisis Lilliefors Test dengan probabilitas $\alpha=0.05$.

Tabel 3. Uji Normalitas Data Body Image Siswa Laki-laki dan Body Image Siswa Perempuan

\begin{tabular}{ccccc}
\hline No & Responden & L $_{\text {maksimun }}$ & L tabel $_{1}$ & Keterangan \\
\hline 1 & Laki-laki & 0.070193 & 0.11 & Normal \\
\hline 2 & Perempuan & 0.055987 & 0.08 & Normal \\
\hline
\end{tabular}

Berdasarkan tabel IV.7 di atas dan sesuai dengan kriteria pengujian $\mathrm{L}_{\text {maksimum }}<\mathrm{L}_{\text {tabel}}$, maka $\mathrm{H}_{0}$ diterima yang artinya distribusi frekuensi data yang kita uji adalah normal. Pengujian homogenitas data untuk variabel body image siswa laki-laki dan body image siswa perempuan dilakukan dengan uji F. Pengujian homogenitas dapat dilihat pada tabel 15 berikut: Tabel 4. Uji Homogenitas Data Body Image Siswa Laki-laki dan Body Image Siswa Perempuan

\begin{tabular}{lllll}
\hline $\begin{array}{l}\text { Body image siswa laki-laki dan } \\
\text { perempuan }\end{array}$ & F & Sig. & df & Ket \\
\cline { 2 - 5 } & 0.026 & 0.872 & 164 & Homogen \\
\hline
\end{tabular}

Berdasarkan hasil perhitungan Tabel IV.8 diperoleh nilai F=0.026 dengan signifikansi 0.872. Karena signifikansi $0.872>$ taraf nyata $\alpha 0.05$ sehingga dapat disimpulkan bahwa ragam dari body image siswa laki-laki dan perempuan tidak berbeda nyata (sama). Hal ini berarti varians 
kelompok populasi adalah homogen. Dengan demikian persyaratan homogenitas untuk analisis komparasi terpenuhi.

Pengujian hipotesis dilakukan dengan menggunakan teknik analisa data $t$ tes. Uji hipotesis dilakukan setelah persyaratan analisis data terpenuhi. Hasil pengujian analisis terhadap data menunjukkan bahwa distribusi frekuensi data yang kita uji adalah normal dan homogen. Adapun hipotesis yang dikemukakan pada penelitian ini yaitu terdapat perbedaan body image siswa laki-laki dan siswa perempuan. Hasil pengujian hipotesis tersebut adalah sebagai berikut:

Tabel 5. Perbedaan Body Image Siswa Laki-laki dan Siswa Perempuan

\begin{tabular}{llllllll}
\hline Perbedaan Body image siswa laki-laki dan & $\mathrm{F}$ & \multicolumn{1}{c}{ Sig. } & $\mathrm{t}$ & $\mathrm{t}$ tabel & $\mathrm{df}$ \\
\cline { 3 - 8 } & & & 0.026 & 0.872 & 2.453 & 1.671 & 164 \\
\hline
\end{tabular}

Berdasarkan Tabel IV.9 di atas, secara lebih rinci hasil analisis data dengan melihat nilai t, maka diperoleh nilai t 2.453 dengan derajat kebebasan (df) 164. Nilai t tabel signifikan 5\% (proporsi dua ekor) adalah 1.671. Karena nilai t yang diperoleh adalah 2.453 sedangkan nilai $\mathrm{t}$ tabel adalah 1.671 maka nilai $t$ hasil lebih besar dari $\mathrm{t}$ tabel ( $\left.\mathrm{t}_{\text {hitung }} \geq \mathrm{t}_{\text {tabee }}\right)$ pada taraf signifikan $5 \%$, dengan demikian terdapat perbedaan yang signifikan. Sehingga diperoleh kesimpulan bahwa terdapat perbedaan yang signifikan antara body image siswa laki-laki dan perempuan.

\section{Pembahasan}

Pada bagian berikut akan dijelaskan pembahasan untuk masing-masing variabel yang dikaji dalam penelitian.

\section{Body Image Siswa Laki-laki}

Berdasarkan hasil penelitian diketahui bahwa rata-rata body image siswa laki-laki berada dalam kategori tinggi dengan persentase sebesar 68.807\%. Rudd dan Lennon (2000) menyatakan bahwa body image adalah gambaran mental yang seseorang memiliki tentang tubuhnya yang meliputi dua komponen. Kedua komponen body image yang dimaksud adalah komponen perseptual (ukuran, bentuk, berat, karakteristik, gerakan, dan perfomansi tubuh) dan komponen sikap (apa yang kita rasakan tentang tubuh kita dan bagaimana perasaan ini mengarahkan pada tingkah laku). Body image pada setiap individu umumnya berbeda, salah satunya yakni jenis kelamin.

Chase (2000) menjelaskan bawa adanya stereotype bahwa jika remaja laki-laki dengan otot yang lebih besar akan membuat dia terlihat lebih percaya diri. Remaja laki-laki ingin 
bertubuh besar dikarenakan mereka ingin tampil percaya diri di depan teman-temannya dan mengikuti trend yang sedang berlangsung. Usaha yang dilakukan remaja laki-laki untuk membuat tubuh lebih berotot dipengaruhi oleh gambar di media massa yang memperlihatkan model remaja laki-laki yang kekar dan berotot. Pada pria tubuh bugar dan penampilan prima dapat menimbulkan citra yang positif.

Beberapa studi menguatkan bahwa kurangnya kekuatan otot menjadi faktor penting bagi laki-laki dalam menimbulkan ketidakpuasan citra tubuh (Cafri \& Thompson, 2004; Olivardia et al, 2004; Paus, Olivardia, Gruber, \& Borowiecki, 1999, dalam Brennan, Maggie A., Lalonde, Christopher E., Bain, Jody L, 2010:131). Menurut Cafri dan Thompson (2004:18) "muscularity is an essential feature of how males think about their bodies". Otot-otot merupakan fitur penting dari bagaimana laki-laki berpikir tentang tubuh mereka.

Selanjutnya Cafri dan Thompson (2004:18) "a muscular male body type is overwhelmingly assigned personality traits with positive connotations (e.g., attractive, strong, happy), whereas skinny and obese body types are ascribed personality traits with negative connotations (e.g., lasy, cheats, sneaky)". Dalam studi ini, tipe tubuh berotot laki-laki diidentikan dengan konotasi positif (misalnya, menarik, kuat, bahagia), sedangkan tipe tubuh kurus dan obesitas diidentikan dengan konotasi negatif (misalnya, malas, menipu, licik).

Berdasarkan pemaparan di atas, maka dapat diketahui bahwa salah satu aspek yang membentuk body image adalah bentuk tubuh. Menurut Furnham, Badmin,dan Sneade (2002:582) "the male ideal is a V-shaped figure with an emphasis placed on large biceps, chest, and shoulders". Dengan kata lain bahwa cita-cita bentuk tubuh laki-laki berbentuk V dengan penekanan ditempatkan pada bisep besar, dada, dan bahu.

Kategori tinggi yang diperoleh siswa laki-laki berkenaan dengan body image juga memberikan makna bahwa siswa positif dalam memandang body image. Body Image yang positif merupakan suatu persepsi yang benar tentang bentuk individu, individu melihat tubuhnya sesuai dengan kondisi yang sebenarnya. Body image positif memiliki sebuah persepsi yang nyata terhadap ukuran dan bentuk tubuhnya, dan merasa nyaman dengannya. Dengan demikian maka guru bimbingan dan konseling seharusnya dapat menyusun program pelayanan agar siswa tetap memiliki citra positif terhadap tubuhnya.

\section{Body Image Siswa Perempuan}

Berdasarkan hasil penelitian, diketahui bahwa body image siswa perempuan tergolong tinggi, berada pada persentase 65, 779 persen . namun jika dibandingkan dengan body image siswa laki-laki masi tergolong rendah. (Grogan, 1999) menyatakan seseorang yang memandang 
penampilan dan tubuhnya dapat disebut body image. Body Image dapat didefenisikan sebagai persepsi, pikiran, perasaan seseorang terhadap tubuhnya sendiri. Charles dan kerr (dalam Grogan, 1999) menemukan bahwa kebanyakan wanita tidak puas dengan body image mereka.Body Image yang negatif inilah memacu wanita untuk memperbaiki penampilan mereka. Kebanyakan remaja wanita mengungkapkan ketidaknyamanan akan bentuk tubuhnya dan ingin menurunkan berat badannya tersebut. Ketidakpuasaan akan bentuk tubuh lebih banyak dialami oleh remaja wanita dibandingkan remaja pria, hal tersebut dapat disebabkan dari berbagai macam hal, seperti keluarga, teman sepermainan,dan juga media, hal yang dapat diakibatkan dari adanya ketidakpuasan akan bentuk tubuh pun bermacam-macam, diantaranya adalah rendahnya kepercayaan diri seseorang. Moore (dalam McCabe \& Ricciardelli, 2004) menemukan bahwa hanya satu pertiga dari remaja laki-laki tidak puas dengan berat badannya, sedangkan dua pertiga dari remaja wanita mengalami ketidakpuasan akan bentuk tubuhnya.

Menurut Santrock (2003:95) “di masa remaja atau pubertas, remaja wanita terlihat lebih tidak puas dan memiliki citra tubuh yang negative dibandingkan dengan remaja laki-laki. Hal tersebut dikarenakan adanya kemugkinan meningkatkan body fat pada remaja wanita, sedangkan remaja laki-laki lebih merasa puas akan bentuk tubuhnya karena di masa inilah otot-otot mereka mulai terlihat". Menurut Furnham, Badmin,dan Sneade (2002:582) "the female ideal is to be extremely thin, with the emphasis placed on slim hips, bottom, and thighs". Bentuk tubuh ideal perempuan adalah sangat ramping, dengan penekanan pada pinggul yang langsing, bagian bawah, dan paha".

Mengingat pentingnya memiliki body image yang positif dan hasil temuan penelitian, maka guru bimbingan dan konseling seharusnya dapat menyusun rencana pelayanan bimbingan dan konseling agar siswa memiliki body image yang postitif, sehingga dapat menunjang kehidupan efektif sehari-hari (KES).

\section{Perbedaan Body Image Siswa Laki-laki dan Siswa Perempuan}

Berdasarkan rangkaian analisis yang peneliti telah dilakukan, diketahui bahwa terdapat perbedaan body image antara siswa laki-laki dan siswa perempuan. Dengan menggunakan t-test diperoleh nilai t sebesar 2.453, sedangkn nilai t tabel sebesar 1.671.

Temuan hasil penelitian di atas membuktikan beberapa teori yang dikemukakan oleh para ahli maupun hasil-hasil penelitian terdahulu. Menurut Chase (2001) gender merupakan faktor paling penting dalam perkembangan body image seseorang. Dacey \& Kenny (2001) juga sependapat bahwa jenis kelamin mempengaruhi body image. Beberapa penelitian yang sudah 
pernah dilakukan menyatakan bahwa remaja perempuan lebih negatif memandang body image daripada remaja laki-laki (Cash\& Brown, 1989).

Remaja laki-laki ingin bertubuh besar dikarenakan mereka ingin tampil percaya diri di depan teman-temannya dan mengikuti trend yang sedang berlangsung. Sedangkan remaja perempuan ingin memiliki tubuh yang langsing, kurus menyerupai ideal yang digunakan untuk menarik perhatian pasangannya

Cash, Morrow et al., (dalam Brennan, Maggie A., Lalonde, Christopher E., Bain, Jody L, 2010:131) melakukan penyelidikan cross-sectional mengenai kepuasan citra tubuh di kalangan mahasiswa pria dan wanita selama jangka waktu 19 tahun. Mereka menemukan bahwa tingkat ketidakpuasan citra tubuh peserta perempuan memburuk dan kemudian diperbaiki dari waktu ke waktu. Para peneliti juga menemukan bahwa tingkat ketidakpuasan citra tubuh laki-laki yang stabil dari waktu ke waktu.

Penelitian yang dilakukan Brennan, Maggie A., Lalonde, Christopher E., Bain, Jody L (2010) mengenai perbedaan body image laki-laki dan perempuan,ditemukan hasil bahwa laki-laki memperoleh skor yang lebih tinggi dari perempuan mengenai skala body image. Hal ini mengindikasikan bahwa laki-laki lebih puas terhadap tubuh mereka dibandingkan perempuan.

Menurut Hetherton \& Hebl (1998:259) "women are more likely than men to evaluate specific body features negatively. Body image dissatisfaction among women is almost invariably related to self perceptions of overweight, whereas dissatisfaction among men is equally divided between worries about being overweight and worries about being underweight'. Wanita lebih mungkin untuk mengevaluasi fitur tubuh tertentu secara negatif,dibandingkan laki-laki. Ketidakpuasan citra tubuh di kalangan perempuan hampir selalu terkait dengan persepsi diri dari kelebihan berat badan, sedangkan ketidakpuasan di kalangan pria adalah sama dibagi antara kekhawatiran tentang kelebihan berat badan dan kekhawatiran tentang menjadi kurus.

Berdasarkan penjelasan di atas, maka dapat disimpulkan bahwa wanita cenderung tidak puas terhadap tubuh mereka. Oleh sebab itu guru bimbingan dan konseling dapat menyusun program pelayanan yang difokuskan pambentukan persepsi mengenai body image yang positif, khususnya terhadap wanita.

\section{PENUTUP}

Berdasarkan temuan dan pembahasan hasil penelitian, maka dapat dikemukakan kesimpulan sebagai berikut. 
1. Body Image siswa laki-laki di SMA Negeri 1 Tanjung Mutiara tergolong pada kategori tinggi. Masing-masing sub variabel yang dikemukakan dalam penelitian ini berada pada kategori baik, yaitu penilaian terhadap bagian tubuh, sedangkan pada indikator puas terhadap bentuk tubuh, puas terhadap berat badan, menganggap penting menjaga body image, menutup bagian tubuh yang kurang menarik, menghindari pembicaraan mengenai bentuk tubuh yang kurang menarik dengan orang lain,berusaha tampil lebih baik, meningkatkan ukuran/bentuk tubuh, berat badan agar ideal, cemas apabila ukuran/bentuk tubuh tidak ideal, membandingkan ukuran/bentuk tubuh dengan orang lain,dan membandingkan berat badan dengan orang lain, berada pada kategori sedang.

2. Body Image siswa perempuan di SMA Negeri 1 Tanjung Mutiara berada pada kategori tinggi. Masing-masing sub variabel yang dikemukakan dalam penelitian ini berada pada kategori baik, yaitu berusaha tampil lebih baik dan meningkatkan ukuran/bentuk tubuh, sedangkan pada indikator penilaian terhadap bagian tubuh, sedangkan pada indikator puas terhadap bentuk tubuh, puas terhadap berat badan, menganggap penting menjaga body image, menutup bagian tubuh yang kurang menarik, menghindari pembicaraan mengenai bentuk tubuh yang kurang menarik dengan orang lain, berat badan agar ideal, cemas apabila ukuran/bentuk tubuh tidak ideal, membandingkan ukuran/bentuk tubuh dengan orang lain,dan membandingkan berat badan dengan orang lain, berada pada kategori sedang.

3. Terdapat perbedaan yang signifikan antara body image siswa laki-laki dan body image siswa perempuan di SMA Negeri 1 Tanjung Mutiara. Hal ini berarti body image siswa laki-laki baik dibandingkan body image siswa perempuan.

\section{REFERENSI}

Ali, M dan M.Asrori. (2004). Psikologi Remaja. Jakarta: Bina Aksara

Arikunto, Suharsimi. (2006). Prosedur Penelitian Suatu Pendekatan Praktik. Jakarta: Rineka Cipta.

Brennan, Maggie A., Lalonde, Christopher E., Bain, Jody L. 2010. Body Image Perceptions: Do Gender Differences Exist?. Psi Chi Journal of Undergraduate Research, (Online), Vol. 15, No. 3, (http://web.uvic.ca/ lalonde/manu-scripts/2010-Body\%20Image.pdf,diakses 21 Mei 2014).

Burns. R.B. (1993). Konsep Diri : Teori Pengukuran, Perkembangan, Perilaku Terjemahan oleh Teddy . 1993. Jakarta: Arcan . (1988). The Self Concept. London: Panbooks 
Cafri, Guy \& Thompson, J. Kevin. (2004). Measuring Male Body Image: A Review of the Current Methodology. Psychology of Men \& Masculinity, (Online) Vol. 5, No. 1, (http://www.ufjf.br/labesc/files/2011/04/Psychology-of-men-mascukinity 2004 Measuring-male-body-image-a-review-of-the-current methodology1.-pdf, diakses 21 Mei 2014).

Chase. (2001) The relationship Between Body Image Mass Index and body image in brazillian Adult (online vol:1 no: 2 ), http://psycology.with lovely heart/.body image./ edu/html diakses 16 maret 2014

Erlamsyah. (1999). Perkembangan Konsep Diri Anak Usia Dini. Padang: FIP UNP

Furnham, Adrian., Badmin, Nicola., \& Sneade, Ian. (2002). Body Image Dissatisfaction: Gender Differences in Eating Attitudes, Self-Esteem, and Reasons for Exercise. The Journal of Psychology, (Online), (http:// citeseerx.ist.psu.edu/viewdoc/download?doi=10.1.1.331.2864\&rep=rep1\&type Epdf, diakses 21 Mei2014).

Hadisuryabrata, MS. (1997). Mengembangkan Citra Diri Yang Positif Jakarta: Obor offset

Heatherton, Todd F \& Hebl, Michelle R. (1998). Body Image. Encyclopedia of Mental Health, (Online), Volume 1, (http://www.dartmouth.edu/ thlab/pubs/98 Heatherton Hebl EMH.pdf, diakses 21 Mei 2014).

Hurlock, E.B. (1999). Perkembangan Anak. (Edisi ke-enam) Terjemahan oleh Med Meitasari Tjandrasa.1990. Jakarta: Erlangga

.(1990). Psikologi Perkembangan: Suatu pendekatan sepanjang rentang kebidupan. (Edisi Kelima). Terjemahan oleh Istiwidayanti \& Soedjarwo. 1999. Jakarta: Erlangga

James. F. Calhoun \& Joan Rosa Acocella (alih bahasa R.S Setmoko.1995) Psikologi Tentang Penyesuaian \& Hubungan Kemanusiaan, Semarang: IKIP Semarang. Press

Jersild, A.T. (1978). The Psychology Of Adolessen (third edition). New York: Macmillan publishing Co.Inc

Lilis S. (2012) Permasalahan yang Dialami Siswa pada Masa Pubertas (Skripsi) Padang : UNP

Mangkuatmodjo, Soegyarto. (1997). Pengantar Statistik. Jakarta: Rineka Cipta.

Mudjiran, dkk. (2007). Perkembangan Peserta didik. Padang : Dirjen Pendidikan Tinggi

Mukhtar, dkk. (2003). konsep diri Remaja Menuju Pribadi Mandiri. Jakarta : PT. Rakasta Samasta

Pudjijogyanti clara, R. (1986). Konsep diri dalam pendidikan. Jakarta : Arcan

Rakhmat, J. (2007). Psikologi Komunikasi. Bandung: Remaja Rosdex Karya Offset

Santrock, J. W. (2003). Adolescence: Perkembangan Remaja. Diterjemahkan oleh Sherly Saragih. Jakarta: Erlangga 
Erlangga

. (2007). Remaja jilid 2. Diterjemahkan oleh Benedictine Widyasinta. Jakarta:

Sarlito Wirawan. S. (2004). Perkembangan Remaja. Jakarta: Rajawali Press

Setyorini. (2010). Harga diri dan prestasi belajar pada remaja yang obesitas (online) Vol:3 No: 1 Journal Psykologi http:// body image remaja/wong sasake/.doc.html.

Sudijono, Anas. (2004). Pengantar Evaluasi Pendidikan. Jakarta: PT. Raja Grafindo Persada

Sudjana. (2001). Metode Statistika. Bandung: Tarsito

Sugiyono. (2010). Metodologi Penelitian: Pendidikan pendekatan kuantitatif, kualitatif, R\&D. Bandung: Alfabeta

(2011). Metode Penelitian pendidikan: pendekatan kuantitatif, kualitatif dan R\&D.

Bandung : Alfabeta

Sujadi, E., \& Setioningsih, L. (2018). Perbedaan Locus of Control Ditinjau dari Etnis. Jurnal Bimbingan dan Konseling Terapan, 2 (2), 128-138.

Sujadi, E., \& Wahab, M. (2018). Strategi Coping Korban Bullying. Tarbawi : Jurnal Imu Pendidikan, 13(2), 21-32.

Supardi. (2012). Aplikasi Statistika dalam penelitian. Jakarta: Ufuk Press

Thalita Amelinda. (2011). Kontribusi Konsep diri terhadap bubungan social siswa Sekolah Menengah Pertama Negeri 3 Pariaman Skripsi tidak diterbitkan. Padang: Universitas Negeri Padang

Yusuf, A.M. (2013). Metodologi Penelitian Kuantitatif, Kualitatif, dan Penelitian Gabungan. Padang: UNP Press. 